\title{
"Pobres mulheres do sertão!": um olhar feminino sobre as mulheres de Goiás no final do século XIX
}

\author{
"Pobres mulheres do sertão!": a feminine look at the women of Goiás in the late \\ nineteenth century \\ Rildo Bento de Souza \\ https://orcid.org/0000-0003-1437-9595 \\ Faculdade de Ciências Sociais da Universidade Federal de Goiás
}

Resumo: O objetivo desse artigo é analisar o olhar feminino sobre as mulheres goianas no final do século XIX, a partir do relato memorialístico de Augusta de Faro Fleury Curado intitulado "Do Rio de Janeiro à Goiás - 1896 (A viagem era assim)". Pretendese, também, compreender o sertão goiano a que a autora se refere, o contexto da escrita da obra e a conjuntura das mulheres no período.

Palavras-chave: Mulher. Sertão. Goiás.

Abstract: The purpose of this article is to analyze the feminine look on women from Goiás in the late nineteenth century, from the memorialistic account of Augusta de Faro Fleury Curado "Do Rio de Janeiro à Goiás - 1896 (A viagem era assim)". It is also intended to understand the hinterland of Goiás to which the author refers, the context of the writing of the work and the conjuncture of women in the period.

Keywords: Woman. Backwoods. Goiás.

\section{Pelos sertões goianos}

Antes de analisarmos as mulheres goianas no relato memorialístico de Augusta Curado, faz-se necessário recuar um pouco no tempo e situar o sertão goiano no final do século XIX. O interesse, por parte da Coroa Portuguesa, pelo território onde hoje compreende os Estados de Goiás e Tocantins, além do Distrito Federal, ocorreu a partir de 1722, quando foram encontradas jazidas de ouro com potencial para exploração. Com a repercussão da notícia, grande número de pessoas - a maioria de escravizados - aglomeraram-se próximos as jazidas onde passaram a se formar improvisados arraiais e uma vida citadina, embora rudimentar. Porém, o ouro de aluvião durou pouco, a partir das duas últimas décadas do século XVIII se acentuou a diminuição da produção aurífera, comprometendo a rentabilidade da sua exploração.

Dessa forma, a região entrou no século XIX em uma condição econômica "deplorável". Com a decadência do ouro, "a população não só diminuiu como se dispersou pelos sertões; os arraiais desapareciam ou se arruinavam e a agropecuária estava circunscrita à produção de subsistência" (Palacín; Moraes, 2008, p. 67). Ademais, a decadência produziu a "ruralização da vida", acompanhada "de uma regressão cultural, que em muitos casos se traduzia numa verdadeira indianização de grupos isolados", que desprezavam o trabalho e cultivavam o ócio, além de possuírem "um sentimento de fracasso e de derrota", em um estado de "permanente apatia, de resignação muito próxima da desesperança” (Palacín, 1979, p. 155-158).

A análise acima permeou grande parte da construção historiografia sobre Goiás.

Esta obra está licenciada sob uma Creative Commons - Atribuição 4.0 Internacional 
Tal leitura, como essa feita pelo historiador Luíz Palacín, foi influenciada pelos relatos dos viajantes estrangeiros que passaram por Goiás durante as primeiras décadas do século XIX1'. Enquanto a Europa vivia o apogeu da Revolução Industrial, com todo o discurso voltado para o trabalho e o aproveitamento das terras, era inconcebível, aos olhos desses forasteiros, pessoas que não trabalhavam e que em tudo dependiam dos seus escravizados; ademais, os viajantes europeus ressaltavam o contraste entre as vastas terras cultiváveis e a condição de extrema miséria de muitas famílias espalhadas pelo território. Entretanto, essas críticas não foram levadas em consideração durante boa parte da produção historiográfica sobre Goiás das décadas de 1970 e 1980. Somente a partir da década de 1990, começaram a ser produzidas, principalmente a partir do Programa de Pós-Graduação em História da Universidade Federal de Goiás, pesquisas históricas que tinham como fontes os documentos de arquivos até então inexplorados que revelaram outras leituras sobre o século XIX (Gumiero, 1991; Moraes, 1995; Bittar, 1997; Rabelo, 2010; Souza, 2014).

E no decorrer do século XIX, aos poucos, surgiram fazendas e pequenos arraiais, contribuindo para o povoamento do território (Bertran, 1994, p. 07). Outrossim, a decadência da mineração não impediu o "desenvolvimento social e cultural", mas apenas deu "lugar a culturas e formas de socialização diferentes daquelas conhecidas no auge da produção aurífera ou daquelas características da modernidade capitalista" (Assis, 2007, p. 20). Desse modo, a sociedade local "orientava-se por outros níveis de preocupações e buscava satisfazer necessidades vitais à sua maneira" (Chaul, 1995, p. 229).

Mesmo considerado isolado, distante do litoral, sem a perspectiva da chegada da estrada de ferro, que só aportaria em Goiás no início do século XX (Borges, 1982) e buscando formas de encurtar as distâncias, tentando viabilizar, por exemplo, a navegação do rio Araguaia-Tocantins (Doles, 1973), havia uma vida cultural bastante movimentada nesses sertões, principalmente nos médios e grandes povoados, como Pirenópolis e a capital, Cidade de Goiás. É de Pirenópolis, por exemplo, o primeiro periódico goiano, que circulou entre 1830 e 1834, denominado de Matutina Meiapontense. Na capital, o Teatro São Joaquim, inaugurado em 1857, é considerado o primeiro de todo o atual Centro-Oeste brasileiro; ademais, em 1864, foi criado o Gabinete Literário Goyano, instituição cultural inicialmente com noventa sócios que angariavam recursos para a aquisição de livros e periódicos de vários lugares do Brasil e do mundo ${ }^{2}$ (Passos, 1982, p. 159). Isso evidencia que havia uma sociedade organizada, acesso a bens culturais, saraus e bailes onde se falava francês (Rabelo, 2010, p. 135), e cujas famílias mais abastadas enviavam os filhos para estudarem na Europa desde o século XVIII (Moreyra, 2015, p. 39).

Porém, para chegar à capital, ou mesmo em Pirenópolis, havia um grande sertão a ser percorrido. Nas várias semanas que durou a viagem, a partir do momento que

\footnotetext{
1 Seis viajantes percorreram a então Capitania e logo após Província de Goiás durante a primeira metade do século XIX. São eles: o naturalista francês Augustin François de Saint-Hilaire; o naturalista austríaco Joahann Emmanuel Pohl; o militar português Luiz D'Alincourt; o botânico inglês Willian John Burchell; o naturalista escocês George Gardner; e o naturalista francês Castelnau.

2 Esses livros e periódicos chegavam à Cidade de Goiás no lombo do cavalo do tropeiro, que fazia a ponte entre o litoral e o sertão. No século XIX, mesmo com o "declínio da mineração e o gradativo desenvolvimento da atividade agropastoril", o tropeiro continuou com a sua mesma função, qual seja, o de abastecer Goiás "com gêneros, víveres, notícias e novidades, ligando esta província, mesmo que precariamente, aos grandes centros do país, viabilizando, abrilhantando e amenizando a vida no coração do Brasil" (Gumiero, 1991, p. 95).
} 
Augusta Curado adentrou o Estado de Goiás, ao atravessar o rio Paranaíba, um território pouco habitado se descortinou, com seus pousos improvisados, comida escassa e total falta de conforto e, muitas vezes, higiene. Entre o sertão decadente e isolado dos viajantes europeus do início, e o sertão que começava a se redesenhar no final do século XIX, com o surgimento de povoados ao longo das estradas, havia muito mais semelhanças que diferenças. E sertão é uma palavra constantemente usada por Augusta Curado; inclusive é dela a expressão que intitula esse artigo: "Pobres mulheres do sertão!". Bem, mas a qual ou a que sertão Augusta Curado se refere?

Em seu trabalho de fôlego sobre a dicotomia existente entre o litoral e o sertão, Nísia Trindade Lima averigua como esse termo se inseriu no campo do discurso político, científico, acadêmico e literário. Essa palavra foi entendida nos "dicionários da língua portuguesa dos séculos XVIII e XIX, em uma dupla ideia - a espacial de interior e a social de deserto, região pouco povoada" e tal concepção permanece até hoje nos glossários. Para, além disso, a esse vocábulo foram atribuídas várias interpretações entre o final do século XIX e o começo do XX, como "sertão enquanto modo de vida associada à atividade pecuária"; "simbiose entre o homem sertanejo e a natureza com seus segredos"; "distância em relação ao poder público e a projetos modernizadores" (Lima, 1999, p. 57-59).

Porém, a partir de 1916 a palavra sertão, além de ser associado a isolamento, atraso e outros adjetivos desabonadores, também se tornou sinônimo de doenças. Em 1912, por solicitação da Inspetoria de Obras contra as Secas, órgão vinculado ao Ministério dos Negócios da Indústria, Viação e Obras Públicas, o Instituto Oswaldo Cruz organizou uma expedição chefiada pelos médicos sanitaristas Artur Neiva (1880-1943) e Belisário Pena (1868-1939), que, durante nove meses, mapeou o quadro nosológico do Norte da Bahia, sudoeste de Pernambuco, sul do Piauí e de todo o território goiano. Quatro anos depois foi publicado o extenso relatório dessa expedição nas Memórias do Instituto Oswaldo Cruz, que descortinou para o litoral a face de um país atrasado, onde "a solidão, a miséria, o analfabetismo universal, o abandono completo dessa pobre gente, devastada moralmente pelo obscurantismo, pelas abusões e feitiçarias, e física e intelectualmente por terríveis moléstias endêmicas" (Neiva; Pena, 1999, p. 220-221). Este relatório tornou-se a égide do movimento pelo saneamento rural na Primeira República e apontou "a doença e não o clima ou a raça, como principal problema para o progresso das regiões” (Lima, 1999, p. 84). O relatório foi muito criticado pela intelectualidade goiana, principalmente nas páginas da Revista Informação Goyana, periódico que divulgava as potencialidades do Estado, editada na então Capital Federal, que o considerou um atentado e um desrespeito à população de Goiás (Lisboa, 2009).

Para esse trabalho adoto sertão a partir do próprio significado que a palavra tinha no século XIX e que, possivelmente, Augusta Curado estava imbuída. Para a autora do relato memorialístico o sertão começou quando saiu da cidade de São Paulo. A partir dali poucas cidades lhe atraíram e o que se viu foram as grandes lavouras de café, no interior paulista, e os largos campos inexplorados e inabitados no restante do caminho.

Em 1896, era esse o sertão que Augusta Curado se deparou em Goiás, uma região que começava a se reestruturar após o período da decadência, com a formação de várias fazendas, criação de gado, exploração de madeira e uma agricultura de subsistência; com arraiais surgindo na beira das estradas, fato que se acentuaria nos anos seguintes com a entrada da estrada de ferro, mas com uma população extremamente desassistida e doente. O que causaria polêmica em 1916, no relatório dos médicos do Instituto Oswaldo Cruz, Augusta Curado também se atentou duas 
décadas antes. No seu relato memorialístico, em tom de desabafo, ela se surpreendeu e se compadeceu com a condição de vida das pessoas que encontrou durante a sua viagem entre o Rio de Janeiro e Goiás, em especial as mulheres.

\section{Sobre o livro e autora}

De acordo com alguns relatos biográficos (Godoy, 2005; Britto, 1974; Curado, 2014) Augusta Curado (1865-1929) foi a primogênita de cinco irmãos, três mulheres e dois homens. Filha de André Augusto de Pádua Fleury e Paula Euphrosina de Faro Fleury, nasceu em Curitiba, quando o pai exercia o cargo de Presidente da Província do Paraná, posteriormente também ocupando a chefia do executivo no Espírito Santo e no Ceará. A família também viveu alguns anos na Europa, quando André Fleury foi enviado por D. Pedro II para estudar o sistema penitenciário da Alemanha, Suécia e Inglaterra. Com residência fixada em Paris, as filhas mais velhas, Augusta e Paulina, foram internas de um renomado colégio. Na capital francesa nasceu o caçula, de nome Paulo, em 1878. Aos quinze anos, em 1881, Augusta Curado ficou órfã de mãe, enquanto a família morava em Fortaleza. Depois desse episódio a família Fleury regressou ao Rio de Janeiro, onde as filhas mais velhas foram internas do Colégio Imaculada Conceição, em Botafogo. Após terminarem os estudos, seguiram para São Paulo, onde o pai se encontrava para dirigir a Faculdade de Direito. Foi nessa ocasião que conheceu e enamorou-se pelo primo, Sebastião Fleury Curado $(1984-1944)^{3}$, que era acadêmico de Direito e, como parente, tinha livre acesso a residência da família.

Após a sua formatura, que ocorreu em 1886, Sebastião Curado regressou à Cidade de Goiás, sua terra natal, devido ter perdido o pai no ano anterior, e de onde prometeu voltar para casar-se com Augusta. Em 1890 ele retornou ao Rio de Janeiro para exercer o mandato de Deputado por Goiás até 1893, ano em que se casou com Augusta Curado, tendo como padrinho, dentre outros, personalidades como Joaquim Nabuco. Desde o fim do mandato até 1896, Sebastião foi sócio do sogro em um escritório de advocacia. Nesse mesmo ano, com o falecimento do pai de Augusta Curado, Sebastião decidiu voltar à cidade natal, para ajudar a mãe viúva a cuidar da família.

Foi nessa viagem que Augusta Curado deixou suas impressões no pequeno livro intitulado "Do Rio de Janeiro a Goiás - 1896 (A viagem era assim)", organizado por sua filha, Maria Paula Fleury de Godoy, que com menos de três anos de idade, acompanhara os pais e o irmão mais novo nesse percurso. A obra, de 73 páginas, possui três edições, a primeira de 1961, a segunda de 1985 e a última de 2005. Em 37 capítulos curtos o relato nos conduz da Central do Rio de Janeiro, em 23 de agosto, até a sua entrada na Cidade de Goiás, em 20 de outubro. Foram quase sessenta dias de viagem percorridos de trem, no lombo do cavalo ou em um banguê.

Alguns autores descrevem a narrativa de Augusta Curado como um diário (Ribeiro, 2008, p. 38; Souza, 2017, p. 17). Porém, na obra a autora deixa escapar que se trata de uma escrita posterior, pois é até mesmo difícil imaginar a escrita de um diário durante o percurso, que se mostrou tão difícil. Sobre o dia 13 de outubro de 1896, por exemplo, Augusta Curado relata: "Não me recordo nada desse pouso, mas sempre é o mesmo quadro, choupana, paiol, curral, chiqueiro, rancho ao lado" (Curado, 2005, p. 63). Há também quem defina o relato como "uma espécie de diário" (Prado, 2019, p.

${ }^{3}$ Foi Promotor Público, Juiz Substituto, Juiz de Direito da Cidade de Goiás, político, jornalista, Professor de Direito. 
75). Não discordo que a narrativa tem a estrutura de um diário, porém, em nenhum momento a autora se refere a ele, ou faz menção à escrita. Como o livro possui vários detalhes é possível que a autora tenha tomado nota de algumas coisas e depois aperfeiçoado o texto. Sua filha, Maria Paula Fleury de Godoy, menciona que a escrita ocorreu em um único suporte, um caderno, com desenhos da autora: "Lamento tenham se perdido uns 'croquis' que ilustravam o caderno de Mamãe" (Godoy, 2005, p. 16). Diante de falta de elementos que nos indique com precisão se o relato foi ou não escrito após a sua chegada à Cidade de Goiás, é que optei, para esse artigo, pelo termo "relato memorialístico", que acho que traduz melhor a obra.

Embora com familiares na então Província, Augusta Curado não nasceu em Goiás, porém, é tida por alguns autores como "a primeira mulher a dedicar-se à literatura em Goiás" (Ribeiro, 2008, p. 11). Sua primeira obra foi publicada em São Paulo em 1891, intitulada Devaneios, reunindo 51 crônicas "que transitam no mundo da fantasia à realidade, religião, idealização da maternidade e muitas são dedicadas aos pais" (Souza, 2017, p. 73).

Dos oito filhos de Augusta Curado ${ }^{4}$, cinco mulheres e três homens, duas delas seguiram seus passos como escritora: Maria Paula Fleury de Godoy e Mariana Augusta Fleury Curado, também conhecida pela alcunha de Nita. Elas escreveram para jornais, revistas e publicaram livros desde o final do século XIX até a década de 1960 (Curado, 2014). Rafaella Sudário Ribeiro, no seu estudo sobre relações de gênero e o empoderamento feminino a partir das escritoras da família Fleury (Augusta, Maria Paula e Mariana), aponta que:

As mulheres da família Fleury fizeram política apesar da limitação do espaço físico e de seus lares, pois mesmo não Ihes sendo permitido o emprego fixo ou trabalho remunerado no hierarquizado "espaço público", utilizaram a paixão pela escrita e a produção de suas obras como estratégias para romper com a obrigatoriedade dos afazeres domésticos. (Ribeiro, 2008, p. 26)

O historiador Paulo Brito do Prado, por sua vez, argumenta que na Cidade de Goiás no período da Primeira República, as mulheres "não eram inibidas, estúpidas ou mesmo se achavam 'reduzidas ao papel de fêmea para os homens', [...] havia as viúvas e trabalhadoras [...] e aquelas mulheres que não se casaram e que, deste modo, precisavam trabalhar" (Prado, 2019, p. 29).

Evidentemente que haviam restrições, noções de honra, preconceitos, marcas de classe e de raça que, interseccionados ao gênero, ofertavam mais ou menos liberdade a elas em diferentes lugares. Todavia fosse se prostituindo nos becos que serpenteiam a cidade, vendendo bolos, lavando roupas, passeando por ruas, praças e outeiros, estudando no Colégio Sant'Anna, escolas particulares e faculdades ou mesmo escrevendo e lendo no Gabinete Litterario Goyano, estas mulheres saiam da esfera privada para tomar lugar na "vida pública". (Prado, 2019, p. 39)

E não só na capital, a Cidade de Goiás, as mulheres se dedicavam à escrita. Entre 1850 e 1865 e entre 1876 e 1882, Rosa das Dores Fleury Curado, conhecida como Inhazinha ${ }^{5}$, por exemplo, produziu um diário escrito em Corumbá e Meia Ponte

\footnotetext{
${ }^{4}$ Maria Paula Fleury de Godoy, André Fleury Curado, Mariana Augusta Fleury Curado, Clarisse Fleury; Hermínia Fleury, Sebastião Fleury Curado Filho, Augusto da Paixão Fleury Curado e Josefina Maria Fleury Curado Piquet.

${ }^{5}$ Há que se destacar que o tio de Inhazinha foi um dos fundadores e redatores do jornal A Matutina Meiapontense, que fizemos menção anteriormente.
} 
(atual Pirenópolis). Da sua mãe, Ana das Dores Fleury Curado, também nos chegaram alguns "trechos de anotações diárias". (Oliveira, 2010, p. 305). Pelo exposto, fica evidente que a família Fleury Curado produziu um considerável número de escritoras. Seja Augusta, Maria Paula, Mariana, Inhazinha e Ana das Dores, além de outras retratadas no estudo de Rafaella Ribeiro (2008). Essas mulheres, perdidas pelo sertão, educadas em colégios franceses ou incentivadas desde criança a escrita, revelam vestígios de uma literatura que fala muito de si e da condição em que se encontravam.

\section{Augusta Curado e as mulheres do sertão goiano}

Nesse tópico ressaltaremos o olhar de Augusta Curado sobre as mulheres com quem se encontrou no território goiano, desde quando atravessaram o rio Paranaíba, que separa Goiás de Minas Gerais, até a capital, a Cidade de Goiás. Ou seja, centraremos a nossa análise do dia 22 de setembro de 1896, quando aportaram na terra goiana por meio de uma balsa que consistia em "duas canoas presas e sobre elas uma larga tábua pregada em roda, cercada de ferros para evitar quedas", até o dia 20 de outubro de 1896, quando, enfim, terminam a viagem chegando ao destino, a cidade natal do marido, Sebastião Fleury (Curado, 2005, p. 46). O percurso de pouco mais de quatrocentos quilômetros durou quase um mês em uma viagem desconfortável no lombo de cavalo, burro, a pé, ou no banguê.

Saindo do Rio de Janeiro, passando por São Paulo e Minas Gerais, a autora percebe o quão diferente era a terra em Goiás, na outra margem do largo rio Paranaíba. "Em tão pequena distância, o solo já é outro: o terreno é pedregoso, as árvores são menores e mais cerradas do que em Minas Gerais, e a terra é amarelada" (Curado, 2005, p. 47).

Nesse sertão de terra amarelada, Augusta Curado deparou-se com o drama de mulheres que pretendemos aqui analisar. Conheceu, antes dos médicos do Instituto Oswaldo Cruz, o isolamento, as doenças, o analfabetismo, a falta de perspectivas, a escassez de alimentos e a insalubridade das habitações, que permearam o cotidiano das mulheres retratadas no relato memorialístico. No dia 23 de setembro de 1896, por exemplo:

À tardinha chegamos no retiro do Antoninho. Nada havia para se comprar. O casal que tomava conta desse Sítio planta o necessário para não morrer de fome. 0 marido ardia em febre num catre; mal de sezões (intermitentes) e a mulher, muito bonitinha, com olhos de gazela espavorida, quase não falava; trazia no colo um menino de meses. Sebastião administrou quinino ao marido e eles - que diziam nada ter - venderam-nos frangos, leite, ovos e abóbora. Ficamos em duas choupanas meio caídas, expostas ao relento; o luar entrava pelos furos do teto e servia-nos de lamparina. Deitamo-nos cedo para seguir no dia seguinte. (Curado, 2005, p. 48)

A "febre" é antes um sintoma do que propriamente uma doença, porém, nos sertões goianos, ela era tratada como uma enfermidade muito temida ${ }^{6}$. Isso ajuda a

\footnotetext{
${ }^{6}$ Somente na Cidade de Goiás, por exemplo, na segunda metade do século XIX, as febres foram a segunda maior causa de óbitos registrados no Hospital de Caridade São Pedro de Alcântara, perdendo apenas para a tuberculose (Magalhães, 2014, p. 116). Além de ser um desafio para os historiadores da saúde e das doenças fazer um paralelo entre as febres com as doenças hoje conhecidas, isso é agravado "pela descrição inexata das febres, redigida por pessoal não médico, como padres, soldados, viajantes estrangeiros ou burocratas do governo", atribuindo diversos nomes como "palustres", "intermitentes", "remetentes" ou "remetentes biliosas", "perniciosas", "pútridas" e "malignas", "sezões" (Karasch, 1999, p. 20).
} 
explicar o motivo da mudança de postura do casal do sítio. Embora não tivessem com sobras para comercializar, pois praticavam uma agricultura que quase não conseguia suprir a subsistência, venderam um pouco de comida somente após Sebastião Fleury administrar uma dose de quinino no enfermo. Nesse período, final do século XIX, era difícil conseguir a quina, uma vez que ela "vinha de longe e custava muito" e que a sua falta "pode ajudar a explicar por que as febres tinham tão má reputação" em Goiás (Karasch, 1999, p. 51-52).

Sem assistência à saúde, restava aos indivíduos do sertão se apegar a fé ou a medicina popular, como quando Augusta Curado, que caminhava com muita dificuldade devido a uma "cabeça de prego" no joelho e, em um dos pousos, uma fazendeira de nome Rita, de quem falaremos mais adiante, Ihe aplicou um remédio caseiro: "uma gema de ovo batida com açúcar na própria casca, uma colherinha de óleo de amêndoa doce e duas pitadinhas de rapé. O fato é que no outro dia, cedo, arrebentou a cabeça de prego, o que me deu um grande alívio" (Curado, 2005, p. 57).

Noutro passo, é importante ressaltar a forma como Augusta de Faro Fleury Curado descreve a esposa do Antoninho, "bonitinha, com olhos de gazela espavorida, quase não falava", e que trazia um menino de poucos meses no colo. No outro dia, "muito cedo, veio nos ver e dizer que o marido tinha amanhecido sem febre e agradeceu muito o remédio que Sebastião dera. Nunca saíra dali, senão uma vez para ir ao Porto Barreiros, onde se casou" (Curado, 2005, p. 49). Como nunca saíra e vivia sozinha com o marido e o filho, criada na fazenda, recebendo poucas visitas, a não ser de viajantes que cruzavam os caminhos e necessitavam de pouso, o olhar amedrontado com que encarou os forasteiros que adentraram a sua casa se justifica. Em lados opostos duas mulheres completamente diferentes, uma da elite, que conhecia as pessoas mais importantes do período, que estudou na França e a outra que pouco ou nada conhecia do mundo para além dos limites do seu quintal.

No dia 25 de setembro de 1896, ao descansarem por duas horas em um arraial, tomaram "cerveja inglesa e muito bom café". Porém, quando quiseram pagar o café, "a mulher não quis receber". Se na casa do Antoninho pouco havia para vender, quiçá para compartilhar, aqui no arraial, que possuía segundo o relato entre 80 e 100 casas, encontraram um pouco de hospitalidade da mulher que os servia, possivelmente, num tipo de bar ou taberna, já que não quis cobrar o café. Podemos aventar a possibilidade de essa mulher ser a dona ou no mínimo funcionária do estabelecimento. Porém, não quiseram ficar no arraial, e a comitiva seguiu meia légua além, "para evitar que os 'camaradas ${ }^{8}$ ' se metessem em brigas e tomassem demais 'Parati' ${ }^{\text {, }}$, bebida que eles

\footnotetext{
7 Furúnculo.

8 O termo camarada é empregado desde o século XVIII, com vários significados e que no século XIX era usado para se referir "a trabalhadores livres ou libertos que eram contratados para desenvolver uma determinada atividade" que poderia ser temporária ou não (Sena, 2013, p. 73). Presentes nos centros urbanos e nas zonas rurais, não constituíam família, pois "levavam uma vida de viajantes solitários" (Tristão, 1998, p. 137). Ademais, era um trabalhador "geralmente de cor", que "recebia salário e se mantinha submisso ao senhor, que o contratava", sujeitando-se "a todo e qualquer serviço" a partir de um "contrato verbal” (Gumiero, 1991, p. 27). Contratados para acompanhar a família Fleury Curado a partir de Araguari, onde terminava a estrada de ferro, vários "camaradas" compunham a comitiva e a autora cita o caso de um deles, de nome Gregório, que resolveu trabalhar em uma grande fazenda de gado onde fizeram pouso, provavelmente de peão ou vaqueiro. "O dono, José Gonçalves, é amigo do Sebastião e nos tratou com todas as honras. [...] Aí ficou Gregório. Senti bem. [...] Que bom rapaz! Verdadeiro tipo de homem do mato. Sempre a cavalo, descalço, bons dentes, espingarda ao ombro e tão serviçal" (Curado, 2005, p. 59). Provavelmente, como tinham relações de amizade com o dono da fazenda, a anulação do contrato verbal do Gregório deve ter acontecido sem maiores problemas.

${ }^{9}$ Aguardente.
} 
apreciam muito" (Curado, 2005, p. 49-50).

Dois dias depois, em 27 de setembro, após armarem a tolda dentro do rancho, foram visitar um homem de nome Teófilo, dono da propriedade, em cuja entrada havia uma grande cruz de madeira. "Perguntei-lhe se alguém tinha morrido ali. - Não, Sá dona, é pra mode Nosso Senhor nos abençoar" (Curado, 2005, p. 51). Esse trecho deve ter chamado muito a atenção da autora, para ela colocar a frase na forma de um diálogo preservando o modo de falar do seu interlocutor. A ausência de membros da Igreja, somado ao território pouco povoado, o elevado índice de analfabetismo e as relações culturais entre negros e indígenas, conspirava para que formas populares de devoção se manifestassem, como, por exemplo, as praticadas pelas Irmandades religiosas (Moraes, 2005). Criada no meio de uma elite intelectual Augusta Curado nunca deve ter visto uma cruz fincada no chão sem que fosse para marcar o local de alguma sepultura.

Porém, não foi somente fora da casa da família do Teófilo que havia surpresas para a Augusta Curado; dentro da residência, após ela e o marido tomarem um "bom vinho" os filhos leite, a "mulher nos fez tomar café que eles coam aqui, já com o açúcar, o que não deixa de ser gostoso" (Curado, 2005, p. 51). Apesar do costume de adoçar o café ser anterior a colonização brasileira (Verardi, 2015), era a primeira vez que a autora via que a adição do açúcar poderia ser feito junto com o pó no processo de coagem.

O olhar de Augusta Curado diante desse novo mundo que se descortinava durante a viagem lhe produziu diversas reações, pressupomos que só confidenciadas no relato. Isso fica evidente no dia 28 de setembro de 1896, quando após uma chuva torrencial que produziu muita lama e piorou os caminhos, a comitiva resolveu parar em uma "choupana" para descansar.

Foi a primeira vez que vi fiar e é interessante trabalho. Toca-se a roda, que está colocada sobre uma tábua movediça, tal qual uma máquina de costura de pé. Num carretel coloca-se o algodão, ainda bruto, e com os dedos polegar e indicador da mão direita vai-se puxando o fio, devagarinho, o qual estende-se, nesse estendimento endurece e fica o algodão forte para fazer roupa. [...]

- Pobres mulheres do sertão!

Para elas, a roca ${ }^{10}$ e o fuso ${ }^{11}$ são os principais ornatos de suas choupanas; dali que sai o algodão pronto para tecer camisas e calças para o marido e os filhos. (Curado, 2005, p. 52-53)

Em todo o relato memorialístico esse é o único diálogo que Augusta Curado se permite fazer, de modo a verbalizar o pensamento de forma mais contundente. "Pobres mulheres do sertão!" é uma frase de grande impacto e que nos permite, a princípio, três interpretações: a primeira versa sobre a extrema pobreza em que essas mulheres viviam sem a possibilidade de comprar suas vestimentas; a segunda diz respeito a condição dessas mulheres que trabalhavam diariamente para fiar e tecer as roupas de toda a família; e, por fim, a terceira é sobre a decoração das casas que consistia apenas no instrumento de trabalho dessas mulheres. Diante do olhar da mulher culta e de posses, era uma vida sem perspectiva e que the causou pena ou espanto. Porém, isso se acentuou no pouso daquele mesmo dia, quando chegaram ao sítio de um "bom velho" chamado Lucio, "casado, e com uma filha moça, Maria". No dia seguinte:

Não pudemos partir por terem desaparecido alguns animais que só foram

\footnotetext{
${ }^{10}$ Máquina que permite fiar. O principal elemento da roca é a roda que gira a partir de um pedal, por onde passa o material a ser fiado.

11 Haste por onde se enrola os fios depois de passarem pela roca.
} 
encontrados à noite. Perdemos esse dia, que passamos, agradavelmente, em companhia do velho Lúcio e da mulher. Boa gente. Conversaram conosco e nos contaram chorando que tinha uma filha muito mal casada e por essa razão temia casar a Maria. A velha fiava, e muito me divertia observá-la. No sítio, tudo em paz; o velho com 79 anos, nunca tinha visto letra de imprensa. A velha sabia as rezas de cor. Os rapazes trabalhavam na roça; a moça criava galinhas. Aprender a ler? Pra quê??? Viviam tão bem assim... (Curado, 2005, p. 54)

Se no "Pobres mulheres do sertão!" percebe-se certo traço de piedade, aqui no "Viviam tão bem assim" nota-se uma fina ironia, que sucedeu a duas perguntas, em tom de espanto: "Aprender a ler? Pra quê???". Augusta Curado provavelmente espantou-se com a conformidade com a vida que esses sertanejos viviam, longe dos grandes centros, sem nenhum tipo de contato com os livros, vivendo para subsistência e tendo as rezas para lhes espantar as doenças e entrar em contato com o sagrado. $E$ no meio desse cenário encontrava-se o drama de Maria, a filha moça do casal de idosos, que temia casá-la para que não tivesse o mesmo destino da irmã mais velha.

Em nenhum momento a autora falou sobre o que realmente queria a Maria: se casar, mesmo que "mal", ou viver e morrer solteira ao lado da família. Se na capital, a Cidade de Goiás, no mesmo período, as mulheres saíam da esfera privada para ocupar posições "públicas", nos sertões elas seguiam a "vontade predominante dos homens que apoiados pelo discurso religioso, silenciaram os desejos das mulheres, tanto é que elas não escolhiam o seu cônjuge, o que era feito pelo pai da noiva" (Souza, 2017, p. 37). Viviam e faziam o que os homens da família queriam.

Nesse sentido, Augusta Curado teve um destino diferente. Como dissemos anteriormente, enamorou-se do primo quando o mesmo era estudante em São Paulo; concluído o curso retornou para Goiás, prometendo voltar para se casarem. Seu pai, "de inicio, tentou demover as ideias da filha querida, receando que, porventura casados, a mudança para Goiás fosse um desencanto para Augusta" (Britto, 1974, p. 194).

Porém, se em relação ao casamento Augusta pôde escolher o marido, e desse modo se distanciava do drama de Maria, por outro lado, mesmo tendo educação e erudição, portava-se como uma boa mãe, mulher e obediente ao marido. Ao abandonar a família, a cidade em que vivia e o seu círculo social para se embrenhar pelos sertões, em condições terríveis, com o intuito de acompanhar o seu marido, Augusta Curado não difere muito das mulheres com quem se encontrou no sertão goiano. No começo da sua narrativa, por exemplo, percebe-se o seu descontentamento com a viagem:

Daí a poucos minutos partiria para voltar quando?... Só Deus sabe. Meu coração sangrava de dor. Ir para tão longe! Deixar os túmulos de meus pais, deixar minhas irmãs tão queridas, meus irmãos, meus parentes, minhas amigas! Saudades, eu já as sentia ali mesmo, perto deles... Quantas lágrimas derramadas na escuridão do carro de praça, e que a custo eu continha depois.

Soou a triste hora da despedida. Como sofri! E a emoção que me foi n'alma, não tentarei descrever! Há coisas que se sente mas que seria impossível tentar exprimir. São notas magoadas que vibram sempre no mais íntimo de noss'alma e que recusam a se fazer ouvir. (Curado, 2005, p. 23)

Há também uma passagem interessante sobre a condição da autora. Caía uma tempestade e "Sebastião a querer, por força, que eu vestisse o ponche de borracha; eu sem querer por que ele pesava muito; afinal, para não desgostar o meu caboclo, enroleime nele" (Curado, 2005, p. 55-56). Embora não quisesse foi obrigada a fazer o que, "por força", o marido desejou.

Durante a viagem, Augusta Curado preocupava-se a todo o momento com os 
filhos pequenos. Talvez por isso, tenha se conformado, no final do relato, quando chegaram à Cidade de Goiás: "o prazer que tive em ver meu marido abraçar sua boa mãe compensou os sacrifícios que, porventura, houvesse feito" (Curado, 2005, p. 68). Podemos presumir que as mulheres eram criadas para casar e servir ao seu marido, de preferência até o fim da vida e sem arrumar outro, caso ficassem viúvas. Na sua caminhada pelo sertão goiano ela se deparou com esses dois casos: a viúva fiel, que se torna a matriarca, controlando os negócios da família e a que se casa novamente.

No primeiro caso temos como exemplo uma senhora de 60 anos, de nome Rita, "uma dessas antigas fazendeiras, cheias de fâmulos", que só "bebe água em copo de prata, as bacias de rosto, de banho, jarras, castiçais, tudo em prata". Era dona de uma "extensa fazenda, com máquina de cortar madeira" movida a dois monjolos, engenho de moer cana e um enorme sobrado com escadaria de pedra. Para além da madeira e da cana, havia grande criação de galinhas, cabras, porcos e gado. Tão logo chegaram nessa propriedade foram recebidos por "duas moças com bandejas de verduras, queijos, leite e biscoitos". Ao visitarem a Rita, notaram-na "toda inchada e, no momento em que falava conosco, teve um terrível acesso de dispnéia. [...] Diz ela que o seu mal vem do fígado" (Curado, 2005, p. 57). A idosa viúva que the curou a "cabeça de prego" com um remédio caseiro, não sobreviveria muito tempo; ao chegarem à Cidade de Goiás o telegrafo já avisara do seu falecimento.

O outro caso também é de uma fazendeira, de nome Delfina, mas diferente da Rita, que ocupa duas páginas, com a primeira Augusta Curado não gasta muitas palavras e a define como "uma pobre criatura sem alma". Porém, o que mais chamou a atenção da autora é o fato de Delfina, ao ficar viúva, "casara-se com um dos 'camaradas' dele". Ademais, ofereceram à comitiva "um cômodo junto ao curral; os bezerros berraram a noite inteira" (Curado, 2005, p. 58). Diante do exposto cabe a seguinte pergunta: como geralmente os "camaradas" eram homens de cor, ou seja, negros, mulatos e mestiços (Gumieiro, 1991, p. 27), será que foi o fato de Delfina casar-se novamente ou será que foi a cor da pele do seu novo marido que horrorizou Augusta Curado?

Sobre Rita e Delfina, enquanto a primeira, mesmo doente, os recebe com toda cortesia e lhes oferece até mesmo o sobrado para passarem a noite, a segunda os trata da pior maneira possível. Percebe-se pela narrativa que Augusta Curado tenta atrelar o caráter com a vida que ambas levavam. Houve outros pousos em que tiveram que dormir ao relento, debaixo de chuva, ou na companhia de carrapatos e pulgas, entretanto, em nenhuma dessas situações a autora tratou os donos dos lugares como criaturas sem alma. Em 14 de outubro, por exemplo, ela escreve: "Chegamos com chuva. Gente boa. Um velho casado com uma moça. O pouso terrível, porém; muitas formigas e porcos rodeando o paiol, grunhindo como uns possessos, não nos deixaram dormir" (Curado, 2005, p. 64). Nota-se que as condições do pouso não diferem muito das oferecidas por Delfina, porém, o casal formado por um velho e uma moça, é definido como "gente boa", ao passo que a outra era uma "criatura sem alma". Isso evidencia que esse casal e a Rita faziam parte de certa normalidade social e que a viúva que casara com o "camarada" do marido não merecesse da parte da autora nenhuma deferência.

Casos como o retratado por Augusta Curado, o "velho casado com uma moça", eram comuns em lugares pouco habitados e isolados. "As mulheres jovens sem bens e que não haviam conseguido casamento numa terra de estreito mercado matrimonial encontravam no homem mais velho, mesmo casado, o amparo financeiro ou social de 
que precisavam" (Del Priore, 2011, p. 66). Em Goiás, principalmente nos pequenos povoados e nas fazendas, prevaleciam as relações de concubinato e "amancebamentos", que foram duramente combatidos pelos bispos durante o século XIX (Silva, 2009, p. 53). No ano em que Augusta Curado situa seu relato memorialístico, 1896, havia seis anos da promulgação do casamento civil no Brasil, culminando na separação em Igreja e Estado.

Em outro pouso, quase chegando ao destino final da jornada, a comitiva deparou-se com um homem viúvo e suas três filhas. Na ocasião, o patriarca da família encontrava-se debilitado, "com febre intermitente" e o marido de Augusta Curado, embora não sendo médico, "deu-lhe uma dose de antipirina, e logo depois, sulfato". Quando foram visitá-lo no outro dia cedo, o homem estava sem febre.

As moças nos deram café e, depois, me ofereceram um cigarro. O quarto estava escuro, pensei que era uma flor, aceitei. Depois vi que era cigarro e fiquei desapontada. Tratei logo de dá-lo a Sebastião. Elas ficaram muito admiradas de eu não fumar. Não faltava mais nada! (Curado, 2005, p. 66)

Não é de se surpreender o assombro de Augusta Curado à reação de admiração das três mulheres ante o fato dela não fumar. Por trás do "Não faltava mais nada!", há todo um contexto em relação a isso. No século XIX as mulheres eram proibidas de fumar, uma vez que era uma atividade estritamente masculina. Na América e na Europa o fumo feminino estava associado à falta de moral, pornografia e prostituição. Em 1908, uma mulher foi presa em Nova York por fumar em público. Porém, no século $X X$, 0 cigarro foi visto como um símbolo da emancipação feminina (Amos; Haglund, 2000, p. 03). Porém, longe dos grandes centros urbanos, em um dos mais pobres estados da recém-criada Federação, sem estrada de ferro e com caminhos improvisados, residiam mulheres que fumavam e eram socialmente aceitas pelas pessoas do entorno. Podemos aventar que por trás desse hábito das mulheres do sertão goiano não havia nenhum bandeira de luta feminista, talvez somente um passatempo em meio a vida que levavam.

Augusta Curado era uma mulher de educação refinada, escritora, pianista e de vasta cultura, não fumava, bebeu algumas vezes durante a viagem a aguardente "Parati", somente para que pudesse suportar o corpo molhado depois de tomar uma chuva, além de ser extremamente obediente ao marido. Embora social e culturalmente distante das mulheres que encontrou no sertão goiano, evidenciando construções de gênero muito diferentes, Augusta Curado viveu para o marido e os filhos, como atesta o relato de sua filha Maria Paula Godoy no prefacio da obra, e isso a torna, de certo modo, igual às mulheres que eternizou no seu relato memorialístico.

Ao encontrar essas mulheres perdidas no sertão goiano com roupas puídas, magras da escassez de alimentos, doentes, que não possuíam de si nem o destino que pertenciam ao pai e aos irmãos, e que fumavam, como a se permitir um pouco de liberdade, Augusta Curado provavelmente repetiu a cada encontro a frase: "Pobres mulheres do sertão!".

O objetivo desse breve estudo foi analisar a narrativa de Augusta Curado a partir do seu olhar sobre as mulheres que encontrou no sertão goiano. O relato memorialístico, embora curto, é cheio de interessantes passagens sobre o modo de vida, o cotidiano e as paisagens naturais nos anos finais do século XIX. 


\section{Referências}

AMOS, Amanda; HAGLUND, Margaretha. From social taboo to "torch of freedom": the marketing of cigarettes to women. TobaccoControl, v. 9, 2000, p. 3-8.

ASSIS, Wilson Rocha. Os Moderados e as Representações de Goiás n'a Matutina Meiapontense (1830-1834). Dissertação (Mestrado em História). Goiânia: Universidade Federal de Goiás, 2007.

BERTRAN, Paulo. "A memória consútil e a Goianidade". In: Ciências Humanas em Revista, v. 5, n. 1. Goiânia: Editora da UFG, 1994, p. 03-08.

BITTAR, Maria José Goulart. As três faces de Eva na Cidade de Goiás. Dissertação (Mestrado em História). Goiânia: Universidade Federal de Goiás, 1997.

BORGES, Barsanufo Gomides. O Despertar dos Dormentes. Dissertação (Mestrado em História). Goiânia: Universidade Federal de Goiás, 1982.

BRITTO, Célia Coutinho Seixo de. A mulher, a história e Goiás. Goiânia: Ed. Líder, 1974.

CHAUL, NarsFayad. Caminhos de Goiás: da construção da decadência aos limites da modernidade. Tese (Doutorado em História). São Paulo: Universidade de São Paulo, 1995.

CURADO, Augusta de Faro Fleury. Do Rio de Janeiro a Goiás - 1896 (A viagem era assim). Goiânia: Kelps/UCG, 2005.

DEL PRIORE, Mary. Histórias Íntimas: sexualidades e erotismo na história do Brasil. São Paulo: Editora Planeta, 2011.

DOLES, Dalísia Elisabeth Martins. As comunicações fluviais pelo Tocantins e Araguaia no século XIX. Goiânia: Oriente, 1973.

FLEURY, Bento. Sequicentenário de Sebastião Fleury Curado, pioneiro das Letras Jurídicas em Goiás. 2014. Disponível em: http://www.atleca.com.br/publicacao.php?id=597. Acesso em 15 de agosto de 2019.

GODOY, Maria Paula Fleury de. Prefácio. In: CURADO, Augusta de Faro Fleury. Do Rio de Janeiro a Goiás - 1896 (A viagem era assim). Goiânia: Kelps/UCG, 2005, p. 09-20.

GUMIERO, Maristela Porfírio da Paz. Os Tropeiros na História de Goiás - Séculos XVIII E XIX. Dissertação (Mestrado em História). Goiânia: Universidade Federal de Goiás, 1991.

KARASCH, Mary C. "História das doenças e dos cuidados médicos na capitania de Goiás". In: FREITAS, Lena Castello Branco Ferreira de (Org.). Saúde e doenças em Goiás: a medicina possível. Goiânia: Ed. UFG, 1999, p. 19-62.

LIMA, Nísia Trindade. Um sertão chamado Brasil: intelectuais e representação geográfica da identidade nacional. Rio de Janeiro: Revan, IUPERJ, UCAM, 1999.

LISBOA, Andreia Silva. O Brazil-Central e suas potencialidades na "Revista A Informação Goyana" (1917-1935). Dissertação (Mestrado em História). Goiânia: Universidade Federal de Goiás, 2009.

MAGALHÃES, Sônia Maria de. Males do Sertão: alimentação, saúde e doenças em 
Goiás no século XIX. Goiânia: Cânone Editorial, 2014.

MORAES, Cristina de Cássia Pereira. Do corpo místico de Cristo: Irmandades e Confrarias na Capitania de Goiás 1736-1808. Tese (Doutorado em História).Lisboa: Universidade Nova de Lisboa, 2005.

MORAES, Cristina de Cássia Pereira. As estratégias de purificação dos espaços na capital da Província de Goiás - 1835-1843.Dissertação (Mestrado em História). Goiânia, Universidade Federal de Goiás: 1995.

MOREYRA, Sérgio Paulo. Vida sertaneja, aspirações metropolitanas: alunos da Universidade de Coimbra nascidos em Goiás. Goiânia: Editora UFG, 2015.

NEIVA, Artur; PENA, Belisário. Viagem Científica pelo norte da Bahia, sudoeste de Pernambuco, sul do Piauí e norte e sul de Goiás. Edição Fac-Similar. Brasília: Senado Federal, 1999.

OLIVEIRA, Adriana Mara Vaz de. Fazendas Goianas: a casa como universo de fronteira. Goiânia: Editora da UFG, 2010.

PALACÍN, Luíz. O século do ouro em Goiás. Goiânia: Oriente. Brasília: Instituto Nacional do Livro, 1979.

PALACÍN, Luíz; MORAES, Maria Augusta de S. História de Goiás. Goiânia: UCG/Vieira, 2008.

PASSOS, Élder Camargo de. "Do Gabinete Literário Goiano". Revista do Instituto Histórico e Geográfico de Goiás. Vol. n 10. Goiânia, Janeiro de 1982, p. 159-183.

PRADO, Paulo Brito do. Aventuras feministas nos sertões de Goiás: as mulheres e as suas lutas nos guardados de Consuelo Ramos Caiado (1899-1931). Tese (Doutorado em História. Niterói-RJ: Universidade Federal Fluminense, 2019.

RABELO, Danilo. A normalização dos comportamentos na Cidade de Goiás (18221889). Goiânia: Universidade Federal de Goiás/Programa de Pós-Graduação em História/FUNAPE, 2010.

RIBEIRO, Rafaella Sudário. Fora da vida: as mulheres da família Fleury (1896-1960). Dissertação (Mestrado em História). Brasília: Universidade de Brasília, 2008.

SENA, Divino Marcos de. Livres e pobres no centro da América do Sul: um estudo sobre os camaradas (1808-1850). Dourados-MS: Ed. UFGD, 2013.

SILVA, Maria da Conceição. Catolicismo e casamento civil em Goiás, 1860-1920. Goiânia: Editora da UCG, 2009.

SOUZA, Rildo Bento de Souza. Pobreza, doenças e caridade em Goiás: uma análise do Asilo São Vicente de Paulo (1909-1935). Jundiaí-SP: Paco Editorial. 2014.

SOUZA, Talita Michelle de. A História de mulheres escritoras em Goiás: atravessando trajetórias e produções literárias. Dissertação (Mestrado em História). Goiânia: Universidade Federal de Goiás, 2017.

TRISTÃO, Roseli Martins. Formas de vida familiar na Cidade de Goiás nos séculos XVIII e XIX. Dissertação (Mestrado em História). Goiânia: Universidade Federal de Goiás, 1998. 
VERARDI, Cláudia Albuquerque. Café: origem e tradição. In: Pesquisa Escolar Online. Recife: Fundação Joaquim Nabuco, 2015. Disponível em:<http://basilio.fundaj.gov.br/pesquisaescolar/index.php>. Acesso em: 20 de agosto de 2019.

\section{Notas de autoria}

Rildo Bento de Souza é licenciado, bacharel, mestre e doutor em História pela Universidade Federal de Goiás. Professor Adjunto do curso de Museologia da Faculdade de Ciências Sociais da Universidade Federal de Goiás. E-mail: rildobento@gmail.com

\section{Como citar esse artigo de acordo com as normas da revista}

SOUZA, Rildo Bento de. "Pobres mulheres do sertão!": um olhar feminino sobre as mulheres de Goiás no final do século XIX. Sæculum - Revista de História, v. 24, n 41 , p. 284-297, 2019.

\section{Contribuição de autoria}

Não se aplica.

\section{Consentimento de uso de imagem}

Não se aplica.

\section{Aprovação de comitê de ética em pesquisa}

Não se aplica.

\section{Licença de uso}

Este artigo está licenciado sob a Licença Creative Commons CC-BY. Com essa licença você pode compartilhar, adaptar, criar para qualquer fim, desde que atribua a autoria da obra.

\section{Histórico}

Recebido em 25/08/2019.

Aprovado em 10/10/2019. 